\title{
Inicjacje bohaterów nieheteronormatywnych w Fanfiku i Slashu Natalii Osińskiej
}

Abstrakt:

Artykuł rozpatruje utwory Fanfik (2016) i Slash (2017) Natalii Osińskiej jako przykłady realizacji nowego modelu młodzieżowej powieści inicjacyjnej w Polsce. W tekście zaprezentowano krótki przegląd stanu badań nad obecnością bohaterów nieheteronormatywnych w literaturze polskiej, zwłaszcza tej przeznaczonej dla młodego odbiorcy. Następnie utwory Osińskiej zostają poddane analizie ze względu na kategorie płci i seksualności. Rozważaniom towarzyszy próba ukazania znaczenia tych kategorii dla fabuły powieści. Ze względu na problemy podjęte przez autorkę tekstu wykorzystane zostają narzędzia związane z LGBT studies, a w szczególności transgender studies.

\section{Słowa kluczowe:}

heteronormatywność, homoseksualność, LGBT studies, literatura młodzieżowa, nieheteronormatywność, powieść inicjacyjna, transgender studies, transpłciowość

\section{The Initiations of Non-heteronormative Characters in Fanfik and Slash by Natalia Osińska}

\section{Abstract:}

The article examines Natalia Osińska's Fanfik [Fanfic] (2016) and Slash (2017) as examples of the implementation of a new model of the young adult coming-of-age novel in Poland. The text presents a short review of the state of research on the presence of non-heteronormative characters in Polish literature, especially in literature intended for the young audience. Osińska's works are then analysed in terms of gender and sexuality, which is accompanied by an attempt to show the meaning of these categories to the plot of the novel. Due to the problems undertaken by the author of the text, tools related to LGBT studies and, in particular, transgender studies, are used.

Key words:

heteronormativity, homosexuality, LGBT studies, young adult literature, non-heteronormativity, coming-of-age novel, transgender studies, transgenderism

* Katarzyna Reszczyńska-Urban - lic., przygotowuje pracę magisterską na Wydziale Polonistyki Uniwersytetu Warszawskiego dotyczącą twórczości Natalii Osińskiej. Kontakt: ka.reszczynska@student.uw.edu.pl. 
T iteratura, której nie ma” - tego sformułowania używa Wojciech Śmieja \⿻ (2010) w tytule swojej publikacji, w której podejmuje temat (nie)obecności wątków homoseksualnych we współczesnej literaturze polskiej. O ile jednak nietrudno zaobserwować zmiany zachodzące w twórczości przeznaczonej dla czytelników i czytelniczek dorosłych, o tyle powieści młodzieżowe nadal podlegają ostrej cenzurze (Nadolna-Tłuczykont, 2017, s. 79). Homoseksualność, w przeciwieństwie do nieokreślanej często heteroseksualności, nieuchronnie kojarzy się z seksualnością, natomiast poruszanie tematów związanych z seksualnością bywa mylnie interpretowane jako próba seksualizacji i deprawacji dzieci. Dlatego właśnie Piotr Sobolczyk (2014, s. 110), poszukując w polskiej literaturze młodzieżowej bohaterów nieheteronormatywnych, odnajduje ich tylko w Musisz to komuś powiedzieć Barbary Ciwoniuk (2010) i Końcu gry Anny Onichimowskiej (2012). Obie autorki niewiele uwagi poświęcają uczuciom towarzyszącym nastolatkom podczas odkrywania seksualności odmiennej od heteronormatywnej. Nie ma tutaj również miejsca na opisy pierwszych doświadczeń erotycznych - w Musisz to komuś powiedzieć taki wątek nie pojawia się wcale, w Końcu gry ogranicza się do kilku zdań. Najpoważniejszym brakiem wydaje się jednak nieobecność historii miłosnej, w którą czytelnicy i czytelniczki mogliby zaangażować się emocjonalnie.

Tego problemu próbuje uniknąć Natalia Osińska (2016, 2017), dlatego w Fanfiku i Slashu ${ }^{1}$ przede wszystkim skupia się na relacji romantycznej łączącej głównych bohaterów. Jako pierwsza w polskiej literaturze młodzieżowej porusza także temat transpłciowości, który ze względu na swoją specyfikę zazwyczaj pojawia się w tekstach o charakterze autobiograficznym, takich jak: Byłam mężczyzna Ady Strzelec (1992), Aleksandra Zamojska jest mężczyzna Daniela Zamojskiego (2005), Brudny róż Kingi Kosińskiej (2015) czy Chłopiec $w$ czerwonej sukience Macieja Lotera (2016). Wyjątkowy przykład stanowi Jedno oko na Maroko Tomasza Kwaśniewskiego (2013), który w swojej reporterskiej książce dla dzieci umieszcza krótki wywiad z transseksualną kobietą. Jak jednak podkreśla Alicja Fidowicz (2016), „znamienny jest brak przedstawień takich osób w literaturze przeznaczonej dla czytelnika nastoletniego" (s. 60). Chcąc wypełnić tę lukę, Osińska decyduje się stworzyć postać Tośka i uczynić go głównym bohaterem obu swoich powieści.

Ze względu na poruszaną tematykę Fanfik i Slash wzbudziły duże zainteresowanie czytelników i czytelniczek. Najpierw pojawiły się pierwsze recenzje, później zaczęły powstawać artykuły dotyczące poszczególnych zagadnień.

1 W artykule nie została uwzględniona powieść Fluff, trzeci tom cyklu Osińskiej (2019) wydany już po powstaniu niniejszego tekstu. 
Anna Kujawska-Kot (2018) zwróciła uwagę na istotną funkcję, jaką pełni fotografia w życiu osób transpłciowych. Maciej Wróblewski (2018) dostrzegł w utworach lewicujący model aksjologiczny. Beata Gromadzka (2018) podjęła się analizy problemu przestrzeni, a Bogusz Malec (2017) zajął się interpretacją metaforycznego znaczenia tytułu pierwszego tomu cyklu. Aleksandra Mochocka (2017) zestawiła tę powieść z Jeżycjadą, Osińska szybko zyskała bowiem miano „Musierowicz naszych czasów” (Szybowicz, 2017). Fanfik i Slash wzbogaciły polską literaturę młodzieżową o - dotąd prawie nieobecne - opisy odkrywania tożsamości nieheteronormatywnej, dlatego warto przyjrzeć się kolejnym inicjacjom głównych bohaterów z perspektywy badań nad płcią i seksualnością.

Fanfik otwiera następująca scena: pierwszego września uczęszczająca do poznańskiego liceum młodzież bierze udział w uroczystej akademii. Dyrektorka zapowiada rok pełen ekscytujących przygód, mówi o zdobywaniu wiedzy i zawieraniu przyjaźni, odkrywaniu nowych lądów i poznawaniu swojego przeznaczenia (Osińska, 2016, s. 7). Tosia wymiotuje w szkolnej toalecie. Przedawkowała antydepresanty, które miały pomóc jej przetrwać ten dzień. Nie dowierza słowom dyrektorki - po kolejnych miesiącach nie spodziewa się niczego dobrego. Nie domyśla się, że naprawdę okażą się one dla niej przełomowe i z głównej bohaterki powieści Osińskiej przekształci się w jej głównego bohatera.

Tosia Graczyk ma szesnaście lat. Mieszka z zapracowanym ojcem, który ze względu na nadmiar obowiązków wychowanie córki powierzył siostrze zmarłej dawno żony. To Idalia gotuje obiady, dba o porządek, chodzi na szkolne zebrania. Pośród wielu zajęć znajduje również czas na pracę - spełnia się zawodowo jako właścicielka salonu urody. Swoją pasję chciałaby dzielić z siostrzenicą, dlatego obdarowuje ją kosmetykami i próbuje nauczyć sztuki makijażu. Chociaż nastolatka nie przejawia zainteresowania własnym wyglądem, pozwala się ubierać i malować:

Całkiem ładna dziewczyna, choć należałoby chyba powiedzieć: bardzo dobrze zrobiona dziewczyna, profesjonalnie umalowana i wykonturowana w sposób, który zmyślnie maskował jej nieco zbyt wydatny podbródek i podkreślał po kociemu kości policzkowe. Duże niebieskie oczy pod wyregulowanymi brwiami. Wokół fale jasnych włosów, przedzielone pośrodku i spływające na policzki. I nie zapominajmy o tej wykwintnej białej kreacji, przylegającej u góry, sutej u dołu, nie pomińmy wypielęgnowanych paznokci, pończoch i lśniących pantofelków (Osińska, 2016, s. 10). 
„Bardzo dobrze zrobiona dziewczyna” - to określenie najlepiej pasuje do Tosi, która nie czuje się naturalnie ze swoją dziewczęcością. Mimo wszystko długo nie próbuje stawiać oporu i podporządkowuje się apodyktycznej Idalii. Ciotka zapewnia jej zwolnienie z lekcji wychowania fizycznego i zabrania pomagać ojcu w pracy. Stara się przekonać siostrzenicę do zajęć uznawanych za typowo kobiece, zachęca do spotkań z koleżankami, każe stale się uśmiechać, a w prezencie kupuje kwiaty doniczkowe. W wyniku tych wszystkich zabiegów szesnastolatka zaczyna wyróżniać się wśród rówieśniczek - nie nosi już przecież butów, lecz pantofelki. Nic dziwnego, że czuje się jak „przerośnięta wersja Alicji w Krainie Czarów” (Osińska, 2016, s. 10) - eksponowana dziewczęcość sprawia wrażenie karykaturalnej.

Pierwszego września, klęcząc w ciasnej kabinie toaletowej, Tosia czuje, że brakuje jej miejsca. Brakuje miejsca dla niej. W sukience z pełnego koła, dodatkowo wzmocnionej sztywną halką, nadal nie potrafi wpisać się w ramy kobiecości wyznaczone przez Idalię. Słysząc rozmowę koleżanek, słyszy przede wszystkim stukot obcasów, dźwięk otwieranych kosmetyczek i najnowsze plotki dotyczące wspólnych znajomych. Dziewczęcy świat ją nudzi i odrzuca, nie czuje się jego częścią. To dziewczyny, nie ona, interesują się modą i godzinami potrafią stać przed lustrem. To dziewczyny ekscytują się aprobującymi spojrzeniami przystojnych kolegów wynagradzającymi ich wysiłki. To dziewczyny analizują SMS-y i komentarze na Facebooku. To dziewczyny zazdroszczą jej urody, kosmetyków, hojnej ciotki i powodzenia u chłopaków. Tosia sobie nie zazdrości. I nie jest dziewczyną.

Jak zauważa Jacek Kochanowski (2011), „kategorie płci to jedne z pierwszych kategorii, które przychodzą nam do głowy po zadaniu nam pytania »kim jesteś?"” (s. 77). Tosia nie potrafi na nie odpowiedzieć. Zdaje sobie sprawę, że dla wszystkich wokół jest Tosią - w domu córką i siostrzenicą, w szkole uczennicą i koleżanką. Sama nazywa się "głupią, tępą Tośką” (Osińska, 2016, s. 89), „popieprzoną dziewczyną” (s. 80) albo ,jednym wielkim problemem” (s. 89). Nie znajduje innych autodefinicji, dlatego nie znosi się przedstawiać. Cierpi za każdym razem, gdy ktokolwiek zwraca się do niej po imieniu, a jeszcze gorzej reaguje na określenia bezpośrednio oznaczające żeńskość, takie jak np. „panna” (s. 41). Czuje, że wcale do niej nie pasują, i zapewne podpisałaby się pod następującym schematem: „Ktoś mnie nazwał X. Nie jestem taka, jak mówią $\mathrm{o} X$. W takim razie to niemożliwe, że jestem $\mathrm{X}$. To jakieś nieporozumienie. Nie jestem X. Na temat X uważam to samo, co większość otaczających mnie ludzi” (Kłonkowska, Bojarska, Witek, 2015, s. 73).

Tosia odnosi wrażenie, że „musi być jakimś obcym, pasożytem zamieszkującym ciało idiotki” (Osińska, 2016, s. 106), którym nawet nie potrafi się 
posługiwać. Z obawy przed rozpoczęciem roku szkolnego i koniecznością zmierzenia się ze światem przekracza czterokrotnie dawkę przepisanych przez doktora Szackiego leków - to dzięki nim popada w stan odrętwienia i łagodnej obojętności. Reakcja organizmu jest natychmiastowa: Tosia walczy ze skurczami żołądka, gardło ma zaciśnięte, próbuje opanować drżenie rąk i odzyskać ostrość widzenia. Kiedy wreszcie jej się to udaje, powoli opuszcza łazienkę i niepewnym krokiem kieruje się w stronę wyjścia. Na schodach poznaje nowego ucznia, który proponuje pomoc. Nie chce jednak narzucić Tosi roli „niewiasty prowadzonej jak bezwolne cielę" (s. 12), wręcz przeciwnie - motywuje ją do działania. Szesnastolatka po raz pierwszy z własnej inicjatywy dzwoni do ojca, żeby zapytać, czy może oddać koledze stare meble. Pożycza od sąsiada wózek mleczarski, zabiera nieużywany dzbanek ciotki Idalii, wreszcie przynosi wiertarkę i przykręca regał do ściany. Czuje się jak „bohater ratujący nieszczęśnika w potrzebie” (s. 19). Wyraźnie widać tutaj próbę odwrócenia stereotypowego wątku „damy w opałach”.

Wkrótce okazuje się jednak, że chociaż Leon nie ma w Poznaniu znajomych, mieszka sam i musi godzić naukę z pracą, to wcale nie wymaga opieki. Tosia wydaje się tym nieco rozczarowana, ale oboje dobrze czują się w swoim towarzystwie i spędzają razem każdą długą przerwę. Niektórzy uważają ich za parę, jednak Leon obiecuje, że Tosia nigdy nie będzie jego dziewczyną. Traktuje ją jak kolegę, nie stara się w żaden sposób zaimponować, a w pewnym momencie komplementuje, mówiąc: „Równy z ciebie chłop” (Osińska, 2016, s. 48). Nie domyśla się nawet, jak bliski jest prawdy. Nie zdaje sobie sprawy, że niedługo oboje staną przed ogromnym wyzwaniem i to właśnie on okaże się przewodnikiem umożliwiającym Tosi transformację (Zwolińska, 2003, s. 119) i będzie towarzyszyć jej w kolejnych inicjacjach.

Pierwsza inicjacja dokonuje się podczas nieobecności Idalii. Tosi skończyły się tabletki, więc nie potrafi zapanować nad emocjami. Widząc Leona wśród kolegów, odczuwa zazdrość i krzyczy, żeby zostawił ją w spokoju. Potrzebuje go jednak i dwa dni później znowu znajdują się razem w ciasnym mieszkaniu chłopaka. Przemoczeni deszczem, przebierają się w ciepłe ubrania. Tosia z ulgą zdejmuje sukienkę i pończochy, wyciera się pożyczonym ręcznikiem. Kiedy przypadkiem patrzy w lustro, nie może już oderwać wzroku: „Mokre włosy miała gładko przyklepane do głowy i zgarnięte do tyłu. Jej twarz, pozbawiona makijażu, ledwie wydobyta z półmroku ostrym światłocieniem, wyglądała blado i bardziej kanciasto niż zazwyczaj. Portki Leona i jego zbyt obszerna bluza dopełniały obrazu" (Osińska, 2016, s. 92). Oczarowana Tosia dotyka swojego odbicia i obserwuje je z zachwytem. W lustrze widzi chudego, wielkookiego chłopaka. Leon, który wraca z łazienki, także go zauważa. „Całkiem przystojny 
z ciebie Tosiek" (Osińska, 2016, s. 92) - stwierdza, tym samym budząc Tośka do życia. Wieczorem Tosia od razu pyta ojca o Daniela. Pamięta, że kiedy podczas rodzinnej kłótni usłyszała to imię, „ogarnęło ją déjà vu. [...] miała wrażenie, że ciocia mówi o kimś bardzo jej bliskim" (s. 66). Wtedy nie naciskała, teraz żąda wyjaśnień. Dostaje kilka starych fotografii, które Idalia wyjęła z albumu i schowała do specjalnej koperty. Na zdjęciach dostrzega podobne do siebie dziecko. Najpierw myśli, że to jej brat, ukrywany przed nią z niewiadomych przyczyn, ale ojciec zaprzecza. „Miałaś... ten etap” (s. 104) - przyznaje, aby dodać po chwili: „Na szczęście z tego wyrosłaś” (s. 105). Opowiada o Danielu bez większych emocji, jak historię pozbawioną znaczenia. Nie rozumie wzburzenia córki, która mówi, że go nienawidzi.

Kiedy Tosia odkrywa, że nie jest Tosią, zaczyna szukać informacji w internecie i powoli upewnia się, że nie jest również ani dziewczyną, ani problemem. Problem stanowi to, że inni uważają ją za dziewczynę, dlatego postanawia działać i przejść kolejną inicjację, która tym razem ,jest efektem świadomego wyboru, potrzeby wprowadzenia zmiany i potrzeby zasygnalizowania zamiaru zmiany" (Kosowska, 2003, s. 235). Na początku Tosiek funkcjonuje oddzielnie od Tosi, która przygląda mu się w lustrze, rozmawia z nim, a nawet przyprowadza go do szkoły. Wbrew obawom Leona nie spotyka się ze skrajnie negatywnymi reakcjami. Kiedy pod wpływem nacisków ojciec po raz pierwszy zwraca się do niej „Danielu”, następuje kolejny przełom i odtąd w narracji miejsce Tosi zajmuje Tosiek. Tosia nie może bowiem nagle stać się Danielem - dokonując przejścia, „przestaje już należeć do kategorii wyjściowej, nie należy jednak jeszcze do kategorii docelowej" (Kłonkowska, 2017, s. 138). Mircea Eliade (1976/1992) twierdzi, że „wszelka inicjacja polega w zasadzie na symbolicznej śmierci” (s. 46) prowadzącej do nowych narodzin. Tosia jako twór Idalii umiera ostatecznie tuż po jej powrocie. Kiedy zamiast siostrzenicy ciotka znajduje Daniela, nie potrafi tego zaakceptować i podejmuje walkę - znowu mówi o sukienkach i doniczkach. Tosiek jest już jednak wystarczająco silny i nie zamierza się poddać. Zamyka się w pokoju i tarasuje wejście. Wyciąga z szafy dziewczęce ubrania i oblewa je farbą, następnie brudnymi rękami powoli obcina jasne włosy. Wreszcie znajduje rozwiązanie i niedługo potem przerażony ojciec zauważa go stojącego na parapecie. Myśląc, że córka chce popełnić samobójstwo, zgadza się uznać ją za syna. „Ja przecież pozwalam!” - krzyczy w rozpaczy. - „Bądź sobie, kim chcesz! [...] Tylko złaź już stamtąd!” (s. 178). Później uświadamia sobie, że to właśnie wtedy „zabił” Tosię.

Tosiek, który na początku planuje jedynie dostać się do rynny i spokojnie zejść po niej na ziemię, w pewien sposób doświadcza jednak śmierci. Po pierwsze, ucieczka okazuje się znacznie trudniejsza, niż przypuszczał. Woli nie myśleć, 
co mogłoby się stać, gdyby nie szybka reakcja ojca, który wbiega po schodach, wyważa drzwi i z powrotem wciąga go do pokoju. Po drugie, zarówno ojciec, jak i Leon, przypisują mu całkiem inne intencje, podejrzewając o próbę samobójczą. Widząc to, Tosiek dopiero wtedy zaczyna się zastanawiać, czy jego życie nie jest tylko „złudą, zlepkiem marzeń i pobożnych życzeń, fanfikiem prawdziwej egzystencji” (Osińska, 2016, s. 177). Chociaż zostaje uratowany, podobne myśli towarzyszą mu jeszcze przez dłuższy czas. Dzięki wsparciu Leona i ojca powoli odzyskuje poczucie bezpieczeństwa. Wypędzona przez szwagra Idalia nie stanowi już zagrożenia. Podobnie jak ona wykreowała kiedyś Tosię, tak teraz - już samodzielnie i z własnej woli - tworzy się Tosiek. Wybiera najbardziej męskie ubrania, eksperymentuje z fryzurą i wykonuje ćwiczenia na poszczególne partie mięśni, bo zdaje sobie sprawę, że „ciało poprzez swoją zewnętrzność, widoczność, wyeksponowanie w kulturze współczesnej staje się medium, za pośrednictwem którego prezentuje się światu to, kim się jest" (Bieńkowska, 2012, s. 28).

Tosiek jest chłopakiem, ale jako chłopak transpłciowy odczuwa silną presję związaną z konformizacją do społecznych wzorców (Kłonkowska, 2017, s. 103) - musi udowodnić innym swoją męskość. Ponieważ jego płeć psychiczna nie odpowiada biologicznej, tym bardziej potrzebuje potwierdzenia $\mathrm{w}$ płci kulturowej. Według Judith Butler (1990/2008) ,jest [ona] powtarzaną stylizacją ciała, zbiorem aktów powtarzanych w wyjątkowo sztywnych ramach regulatywnych, które z czasem zastygają, tworząc pozór substancji, pozór pewnego rodzaju naturalnego bytu" (s. 94). Właśnie dlatego Tosiek odrzuca bierność i nie tylko chętnie wyraża swoje zdanie, lecz także szuka okazji do dyskusji. Poza tym demonstracyjnie łamie kolejne zakazy, buntuje się, zaczyna kląć i przejawiać zachowania agresywne. Jak zauważa Franco La Cecla (2000/2014): „Mężczyźni muszą wykazać, że są prawdziwymi mężczyznami, aranżując hałaśliwe przedstawienie: huk Harleya Davidsona, pisk opon hamującej Vespy, odpowiednio dobrany ton głosu. W przeciwnym wypadku ich płeć pozostanie niewidoczna, niebezpiecznie neutralna" (s. 52). Tosiek obawia się tej neutralności. Czuje, że jako osoba transpłciowa musi odegrać swoją płeć dokładniej, bardziej intensywnie (Strzelecka, 2004, s. 484). Próbuje wpisać się w stereotyp prawdziwego mężczyzny jako jednostki szorstkiej, dominującej i nieustraszonej (Bartosz, Cieślik, Jaz, Kanafa, Zubik, 2004, s. 380). Męskość stara się budować przede wszystkim w opozycji do rodzaju żeńskiego (Ciaputa, 2011, s. 433), dlatego niezmiennie gardzi dziewczynami i nie pozwala sobie na okazywanie uczuć. Udaje, że opinia innych nie ma dla niego żadnego znaczenia, ale tak naprawdę to właśnie inni mogą uprawomocnić jego zmianę statusu - polegającą przecież na „wyjściu danej jednostki z określonej kategorii społecznej i przywróceniu jej do społeczeństwa w nowej kategorii” (Kłonkowska, 2017, s. 138). 
Początkowo Tosiek zostaje odrzucony przez koleżanki, które boją się plotek. Powoli jednak wszyscy przyzwyczajają się do Tośka i zaczynają zwracać się do niego właściwym, męskim imieniem. Chłopak otrzymuje również wsparcie od wielbicieli jego internetowej twórczości. W procesie społecznej tranzycji istotną rolę odgrywa także Idalia, która zostaje wezwana do szkoły z powodu agresywnego zachowania Tośka. W końcu zmienia swoje nastawienie, rozmawia z dyrekcją i odtąd nikt nie wspomina już o Tosi Graczyk - Tosia przekształca się po prostu w Graczyka i na dodatek znajduje się pod stałą opieką grona pedagogicznego. Ciotka daje siostrzeńcowi pieniądze na nową fryzurę i ubrania, a nawet wręcza w prezencie upragniony binder. Mogłoby się wydawać, że w związku z odczuwaną dysforią Tosiek będzie dążył do korekty płci biologicznej. Początkowo nie zastanawia się jednak nad tą kwestią, żyje w „tęczowym świecie własnych wyobrażeń" (Osińska, 2016, s. 195). Wzbrania się przed wizytą u specjalisty, nie zaczyna terapii hormonalnej. Nie zamierza także pozywać ojca do sądu w celu wprowadzenia zmiany w akcie urodzenia. $\mathrm{Na}$ razie jest Tośkiem i marzy, żeby w przyszłości stać się Danielem. Osińska nie unika jednak problemu seksualności. Głównym tematem Fanfika i Slasha czyni nie tylko kolejne przemiany Tośka, lecz także jego relację z Leonem, której opis staje się osią fabularną obu powieści².

Początkowo cała historia wydaje się mało prawdopodobna. Bohaterowie bardzo szybko się zaprzyjaźniają. Poznają się pierwszego września i już tego dnia wybierają się razem na zakupy, a potem wspólnie urządzają mieszkanie Leona. Tosia, która jeszcze nie odkryła w sobie Tośka i zazwyczaj nie potrafi odnaleźć się wśród ludzi, w towarzystwie nowego kolegi czuje się zaskakująco swobodnie. Wreszcie nie musi spełniać cudzych oczekiwań - Leon niczego od niej nie wymaga i przede wszystkim, w przeciwieństwie do swoich rówieśników, nie traktuje jej jako obiektu seksualnego. Paradoksalnie właśnie dlatego, że widzi w niej dziewczynę, Tosia może poczuć się chłopakiem. Jak bowiem okazuje się później, Leon jest gejem. O ile jednak Tosiek odkrycie własnej tożsamości nazywa „totalnym odlotem” (Osińska, 2017, s. 199), o tyle dla Leona orientacja seksualna staje się źródłem poważnych problemów. Nastolatek musi opuścić rodzinny dom i wyprowadzić się do Poznania. Wyśmiewany w poprzedniej

2 Nawiązując do tytułów powieści, warto dodać, że fanfik to spolszczenie słowa fanfic, czyli fikcji fanowskiej, slash odnosi się do „[fanowskich] utworów pornograficznych”, w których „fabuła ma charakter pretekstowy”, często ukazujących „bohaterów tej samej płci”, a - to już odniesienie do nieomawianego tu szczegółowo tomu cyklu -,„w przypadku podgatunku o nazwie fluff środek ciężkości zosta[je] położony na elementach komicznych" (Werra, 2016, s. 480). 
szkole, w nowej za wszelką cenę stara się pozyskać sympatię otoczenia. Tosia, która przyciąga uwagę swoimi wyszukanymi strojami i perfekcyjnym makijażem, bardzo pomaga mu w kreowaniu odpowiedniego wizerunku. Szybko zostaje uznana za jego dziewczynę, dzięki czemu Leon może zacząć spotykać się z Konradem, nie narażając się na niczyje podejrzenia. Wkrótce jednak wszystko zmienia pojawienie się Tośka. Tosiek zdecydowanie nie spełnia swojej funkcji. Mimo wielu obaw Leon nie chce się z nim rozstawać, wręcz przeciwnie - coraz bardziej mu na nim zależy. Chociaż cały czas przejmuje się opinią innych, nie martwi się już wyłącznie o siebie - w trosce o Tośka proponuje mu np. żeby udawał, że przegrał z nim zakład i dlatego musi chodzić w męskich ubraniach. Poza tym zawsze stara się być blisko i zapewnia, że cokolwiek się stanie, przejdą przez to razem. Mimo wszystko ma nadzieję, że znajomi nie domyślają się prawdy i w ich oczach jest „kimś w rodzaju biednego Rochestera, pokaranego przez los dziwnym związkiem z pyskatą osóbką, której się trochę popieprzyło w głowie" (Osińska, 2017, s. 69). Z błędu wyprowadza go dopiero Emilia, która oburza się, kiedy zaprasza ją na wesele Sandry, starszej siostry: „Kogo ty chcesz oszukać. Masz mnie za idiotkę? Tosiek to teraz chłopak, tak? Wszyscy się już przyzwyczaili. Nikogo to nawet nie rusza [...]. A ty, zamiast znaleźć sobie inną dziewczynę, oczy masz coraz bardziej maślane” (Osińska, 2017, s. 128).

Podobnie sytuacja przedstawia się po drugiej stronie. O ile Tosia nie przejawia zainteresowania chłopakami i poza kilkoma męczącymi randkami oraz nieudaną studniówką nie ma żadnych romantycznych doświadczeń, o tyle Tosiek prawie od razu zakochuje się w Leonie. Leon pierwszy zdobywa się na wyznanie uczucia. Na początku mówi tylko oszczędnie: „Myślę o tobie same dobre rzeczy" (Osińska, 2016, s. 202). Kiedy jednak przed świętami Tosiek ze smutkiem patrzy na otaczające ich pary i dochodzi do wniosku, że jako „wybryk natury" (s. 364) nigdy nie doświadczy podobnego szczęścia, w odpowiedzi słyszy zapewnienie o „romantycznym lubieniu” (s. 364). Zupełnie się tego nie spodziewa i na początku nie potrafi ukryć zaskoczenia, ale po chwili popada w euforię i pozwala się pocałować. Decydując się na związek z chłopakiem, Tosiek przestaje pasować do obowiązującego schematu osoby transpłciowej, która „w głębi duszy jest typowym heteroseksualistą, tyle że zamkniętym w ciele innej płci” (Bieńkowska, 2012, s. 37). Zgodnie ze społecznymi oczekiwaniami powinien poszukać dziewczyny, żeby w ten sposób ostatecznie potwierdzić swoją męskość (Kłonkowska, 2017, s. 93). Co ciekawe, wcale jednak nie martwi się tą kwestią. Istotnym problemem okazuje się natomiast wyrażanie uczuć, kojarzące mu się z kobiecością.

Jak zauważa Roland Barthes (1977/2011) we Fragmentach dyskursu miłosnego, „mężczyzna nie jest zniewieściały dlatego, że może być homoseksualistą, 
lecz dlatego, że jest zakochany" (s. 24). Tosiek stara się tego wystrzegać i w pewnym momencie słyszy od Leona: „Nie ma w tobie za grosz romantyzmu [...]. Złapać za pysk, obcałować, obrazić, krótka instrukcja relacji międzyludzkich made by Tosiek" (Osińska, 2017, s. 20). Próbuje jednak pracować nad swoim zachowaniem - niedługo potem zaprasza Leona na randkę i zadowolony wręcza mu kwiatek, po czym słyszy: „Nie będę szedł z tym badylem przez miasto” (s. 75). Tak naprawdę to bowiem Leon ma większy problem - nie potrafi uwolnić się od zinternalizowanej homofobii polegającej na „braku akceptacji własnej nieheteroseksualnej tożsamości” (Nowak, 2014, s. 199). Cały czas czuje się gorszy od innych i boi się ich oceny. Myśli o rodzicach, którzy się go wstydzą. Próbuje nie myśleć o wujku, który z krzykiem wyrzucił go z domu. Przypomina sobie Maćka, którego dotkliwie pobił tylko dlatego, że chłopak ośmielił się zapytać, czy mu się podoba. O ile związek z Tosią wydaje się dobrym pomysłem pozwalającym uniknąć wielu przykrości, o tyle relacja z Tośkiem okazuje się znacznie bardziej skomplikowana. Jako para jednopłciowa muszą liczyć się z różnymi reakcjami społeczeństwa. Witold nazywa ich dziwadłami i patologią, a Darek, przypadkowy świadek pierwszego pocałunku, nie chce siedzieć obok w ławce. Nauczycielka wychowania do życia w rodzinie z zażenowaniem wspomina o „nich” - „kosmitach, którzy [...] łączą się w konfiguracje nieobjęte podręcznikiem" (Osińska, 2017, s. 220). Przepełniony strachem Leon nieustannie drży przed „ludźmi, którzy z rezerwą podchodzą do braku poszanowania dla Zasad” (Osińska, 2017, s. 65) i „ludźmi, którzy mają Poglądy” (s. 65). Chociaż zależy mu na Tośku, woli pozostawać w ukryciu i wzbrania się przed publicznym manifestowaniem uczuć. To, co dla par heteroseksualnych jest zupełnie naturalne, czyli np. trzymanie się za rękę, dla niego okazuje się barierą nie do przekroczenia. Przeraża go niefrasobliwość Tośka, który zaczyna uczęszczać na spotkania jakiejś podejrzanej grupy i razem z nią zajmuje się organizacją poznańskiego Marszu Równości. Leon zapewnia, że nigdy do nich nie dołączy. Prosi Tośka: „A siedź sobie w tym tęczowym bąbelku, po prostu mnie w niego nie wciągaj” (s. 80).

Leon długo nie potrafi zdobyć się na coming out. W wyniku różnych zawirowań ostatecznie musi pojawić się na marszu, ale wcześniej odpowiednio się do niego przygotowuje. Chcąc uzyskać niedbały wygląd, odbiegający od stereotypowego wyobrażenia geja, wybiera wytartą bluzę, nie goli się i nie układa fryzury. W przeciwieństwie do Tośka, który przed lustrem najpierw odkrywa siebie, a potem próbuje tego siebie jak najlepiej wyrazić, Leon stara się stworzyć pewnego rodzaju kamuflaż, ukryć część własnej tożsamości. Kiedy jednak udaje mu się osiągnąć cel i grupa przeciwników marszu uznaje go za kogoś o podobnych poglądach, wreszcie się przełamuje, zaprzecza i mówi: „Tosiek 
tam jest. Mój chłopak tam jest" (Osińska, 2017, s. 167). Chociaż w efekcie zostaje pobity, paradoksalnie właśnie wtedy przestaje się bać. Na dodatek wkrótce uświadamia sobie, że kocha Tośka. Dzięki temu kolejne coming outy okazują się dużo łatwiejsze - rozmawiając z Idalią o jej siostrzeńcu, Leon znowu nazywa go swoim chłopakiem. Wieczorem tłumaczy matce przez telefon: „Tosiek to nie zachcianka [...]. To... to właśnie moje życie. Innego nie będzie” (Osińska, 2017, s. 207). Kiedy Sandra zauważa ich wspólne zdjęcie i pocztówkę, Leon opowiada jej o wszystkim i zostaje zrozumiany - siostra denerwuje się tylko, że tak długo o niczym nie wiedziała. Później spotykają się we troje na Czarnym Proteście wtedy Leon, do tej pory owładnięty strachem i wzbraniający się przed jakimikolwiek etykietkami, przejmuje od Tośka tęczową flagę i niesie ją przez miasto.

Barthes (1977/2011) wyznanie miłości nazywa „wydawaniem głosu” (s. 232). W postępowaniu Leona można zauważyć kilka takich przełomowych momentów. Najpierw zdobywa się na głos sprzeciwu wobec homofobii, potem decyduje się na kolejne coming outy i stopniowo ujawnia własną homoseksualność. Wbrew wcześniejszym zapewnieniom zabiera głos na zebraniu grupy organizującej Marsz Równości, przestaje kłamać i w końcu mówi Tośkowi o swojej trudnej przeszłości, żeby wreszcie przyznać, że go kocha. Na początku wydaje się, że ze względu na historię z Maćkiem zostaje odrzucony, ponieważ Tosiek nagle wychodzi, jednak przyczyna okazuje się inna: „Gdy zacząłeś opowiadać o tym... chłopaku, to wtedy akurat, wtedy akurat... - Tosiek wykrzywił się, zacisnął powieki i wymamrotał bardzo niewyraźnie: - ... to wtedy akurat m-mi się okres zaczął i zupełnie nie wiedziałem, co mam robić!” (Osińska, 2017, s. 302). Czuje się upokorzony, ale próbuje się przełamać i dzieli się swoimi obawami, stwierdzając, że Leon kocha go tylko „od szyi w górę” (s. 310). Chłopak gwałtownie zaprzecza i zapewnia, że Tosiek wcale nie musi przyjmować hormonów - dla niego i tak jest Danielem.

Wydaje się zatem, że w ich relacji cielesność nie stanowi najważniejszego problemu. Mimo wszystko opóźnia jednak inicjację seksualną. Chociaż Grzegorz Leszczyński (2010) zauważa, że dla młodych ludzi „nie jest [ona] - jak w niegdysiejszej prozie - kluczowym czy choćby istotnym, znaczącym, ważnym wydarzeniem [...], przeciwnie: jest doświadczeniem oczywistym, epizodem, który - niczym choroby wieku dziecięcego - po prostu się przechodzi" (s. 52), w przypadku Tośka i Leona dzieje się inaczej. Nie można nawet mówić o jednym kluczowym momencie, ale o całym szeregu inicjacji. Dopiero we właściwym wcieleniu Tosiek decyduje się z własnej woli nawiązać kontakt fizyczny i głaszcze Leona po policzku, po czym zmieszany cofa dłoń. Później stopniowo coraz bardziej przekonuje się do bliskości. Ze względu na jego odmienność każde publiczne wyrażenie uczuć staje się nie tylko kolejną inicjacją 
seksualną, lecz także pewnego rodzaju inicjacją społeczną - przekroczeniem obowiązujących norm i ukazaniem się światu jako para jednopłciowa.

W okresie dojrzewania bohaterowie nieheteronormatywni zmagają się z wieloma problemami - zarówno tymi, które dotyczą większości ich rówieśników, jak i specyficznymi trudnościami wynikającymi z pewnej odmienności. Kategorie płci i seksualności, bardzo ważne dla młodych ludzi, muszą zostać przez nich odkryte na nowo. Kształtowanie tożsamości okazuje się wyjątkowo skomplikowane, ponieważ wiąże się z koniecznością zanegowania poprzedniej, tej narzuconej i zgodnej z przyjętymi normami. Tosiek najpierw odrzuca dziewczęcość, pozbywa się atrybutów kobiecości i dopiero potem stopniowo przyjmuje rolę męską. Leon zaprzecza swojej domniemanej heteroseksualności, dokonując szeregu coming outów. Obaj spotykają się z różnymi reakcjami społeczeństwa, m.in. transfobią i homofobią, dlatego w przeciwieństwie do rówieśników dość szybko angażują się w działalność wykraczającą poza dom i szkołę. Jako przedstawiciele mniejszości poszukują grup wsparcia i czują potrzebę kształtowania wspólnej tożsamości politycznej - stąd np. organizacja poznańskiego Marszu Równości.

Pisząc o Innych, Osińska stara się nie powielać stereotypów. Chociaż nie zawsze jej się to udaje, warto zauważyć, że autorka tworzy bohaterów, których można polubić, identyfikować się z nimi i zaangażować się emocjonalnie w ich relację. Skupia się na historii miłosnej i - wbrew dominującej tendencji do ukazywania nieustannego cierpienia par jednopłciowych - w obu powieściach decyduje się na szczęśliwe zakończenie. Tosiek i Leon zostają zaakceptowani przez większość rodziny i znajomych, mogą liczyć na wsparcie i zrozumienie, a przede wszystkim się kochają. O ile Leszczyński (2010, s. 54) stwierdza, że dla młodych ludzi miłość przestaje mieć jakiekolwiek znaczenie, o tyle w przypadku Tośka i Leona sytuacja wygląda zupełnie inaczej. Obaj wyznają sobie uczucie, próbują się zrozumieć i uczą się wybaczać. Mimo że muszą zmagać się z wieloma problemami, podejmują wyzwanie, starając się zmienić siebie i otaczający ich świat. Optymistyczne przesłanie powieści zostaje zresztą zapowiedziane już na samym początku cyklu. Mottem Fanfika Osińska czyni słowa piosenki Elfaby z musicalu Wicked (Schwartz, Holzman, 2003) bazującego na tak samo zatytułowanej powieści Gregory’ego Maguire’a (1995/2010), która z kolei odnosi się do Czarnoksiężnika ze Szmaragdowego Grodu L. Franka Bauma (1900/2018) i filmu na jego podstawie (LeRoy, Fleming, Cukor, Taurog, Thorpe, Vidor, 1939) - tym samym pisarka palimpsestowo nawiązuje do wyrażających pochwałę inności ikonicznych tekstów kultury LGBT (Krakowska, 2018; Skowera, 2016). Autorka czerpie również z konwencji powieści inicjacyjnej, w której - jak zauważa Elżbieta 
Kruszyńska (2003) - „występuje albo wielość momentów inicjacji, zatarcie granicy między dzieciństwem a dorosłością, albo podział na okres przed i po wtajemniczeniu" (s. 630). Twórczyni Fanfika i Slasha wykorzystuje jednak oba zabiegi, zwracając uwagę na pewną stałą zmienność. W celu podkreślenia tej płynności nie decyduje się na typowe zakończenie - bohaterowie nie osiągają pełnej dojrzałości, przekraczają tylko kolejne etapy. Kształtowanie tożsamości nie jest bowiem stanem statycznym, lecz "niepowtarzalnym, złożonym, wielopoziomowym, dynamicznym i interaktywnym procesem" (Kłonkowska, Bojarska, Witek, 2015, s. 75).

\section{Bibliografia}

Barthes, R. (2011). Fragmenty dyskursu miłosnego (M. Bieńczyk, tłum.). Warszawa: Aletheia. (wyd. oryg. 1977).

Bartosz, B., Cieślik, A., Jaz, M., Kanafa, D., Zubik, A. (2004). Co zobaczą kobiety, a co dojrzą mężczyźni, kiedy popatrzą na siebie? W: A. Kuczyńska, E. Dzikowska (red.), Zrozumieć pteć. Studia interdyscyplinarne II (s. 378-396). Wrocław: Wydawnictwo UWr.

Baum, L. F. (2018). Czarnoksiężnik ze Szmaragdowego Grodu (S. Wortman, tłum.). Warszawa: Dwie Siostry. (wyd. oryg. 1900).

Bieńkowska, M. (2012). Transseksualizm w Polsce. Wymiar indywidualny i społeczny przekraczania binarnego systemu płci. Białystok: Wydawnictwo UwB.

Butler, J. (2008). Uwikłani w płeć. Feminizm i polityka tożsamości (K. Krasuska, tłum.). Warszawa: Wydawnictwo Krytyki Politycznej. (wyd. oryg. 1990).

Ciaputa, E. (2011). Jak płeć stawała się rodzajem. W: K. Slany, B. Kowalska, M. Ślusarczyk (red.), Kalejdoskop genderowy. W drodze do poznania plci społeczno-kulturowej $w$ Polsce (s. 427-443). Kraków: Wydawnictwo UJ.

Ciwoniuk, B. (2010). Musisz to komuś powiedzieć. Łódź: Literatura.

Eliade, M. (1992). Okultyzm, czary, mody kulturalne. Eseje (I. Kania, tłum.). Kraków: Oficyna Literacka. (wyd. oryg. 1976).

Fidowicz, A. (2016). Bohater nieheteronormatywny w powieści Nad czarnq woda Haliny Górskiej. Zeszyty Naukowe Towarzystwa Doktorantów UJ. Nauki Humanistyczne, 15(4), 57-71.

Gromadzka, B. (2018). Szkoła - dom - okolica. Wartościowanie przestrzeni w literaturze dla młodzieży. Polonistyka. Innowacje, 7, 59-70. https://doi.org/10.14746/ pi.2018.1.7.5.

Kłonkowska, A. (2017). Płeć: dana czy zadana? Strategie negocjacji (nie)tożsamości transplciowej $w$ Polsce. Gdańsk: Wydawnictwo UG.

Kłonkowska, A., Bojarska, K., Witek, K. (2015). O płci od nowa. Własna tożsamość oczami osób transpłciowych. Gdańsk: Wydawnictwo UG. 
Kochanowski, J. (2011). Płeć, seksualność i kondycja postkolonialna. Queer studies a sprawa polska. W: K. Slany, J. Struzik, K. Wojnicka (red.), Gender w społeczeństwie polskim (s. 70-81). Kraków: Nomos.

Kosińska, K. (2015). Brudny róż. Zapiski z życia, którego nie było. Warszawa: Nisza.

Kosowska, E. (2003). Kulturowe inicjacje Martina Edena. W: W. Gutowski, E. Owczarz (red.), Z problemów prozy. Powieść inicjacyjna (s. 235-253). Toruń: Dom Wydawniczy Duet.

Krakowska, J. (2018). Nie jesteśmy w Kansas, czyli geje tłumaczą nam świat. Dialog, 10(743), 135-141.

Kruszyńska, E. (2003). Inicjacja w powieściach dla dziewcząt w dwudziestoleciu międzywojennym (na przykładzie powieści Heleny Boguszewskiej Za zielonym wałem oraz Anielcia i życie). W: W. Gutowski, E. Owczarz (red.), Z problemów prozy. Powieść inicjacyjna (s. 630-639). Toruń: Dom Wydawniczy Duet.

Kujawska-Kot, A. (2018). Od impulsu fotografii do narracji tożsamościowej. Funkcje fotografii bohaterów transpłciowych w ich życiu. Rynek - Społeczeństwo - Kultura, 1(27), 91-99.

Kwaśniewski, T. (2013). Jedno oko na Maroko. Warszawa: Czarna Owieczka.

La Cecla, F. (2014). Szorstkim być. Antropologia mężczyzny (H. Serkowska, tłum.). Warszawa: Sic!. (wyd. oryg. 2000).

LeRoy, M. (prod. i reż.), Fleming, V., Cukor, G., Taurog, N., Thorpe, R., Vidor, K. (reż.). (1939). The Wizard of Oz [Czarnoksiężnik z Oz] [film]. USA: MGM.

Leszczyński, G. (2010). Bunt czytelników. Proza inicjacyjna netgeneracji. Warszawa: Wydawnictwo SBP.

Loter, M. (2016). Chłopiec w czerwonej sukience. Chorzów: Videograf.

Malec, B. (2017). Ludzie są jak „fan fiction”. Na przykładzie Fanfika Natalii Osińskiej. Artes Humanae, 2, 175-187. http://doi.org/10.17951/arte.2017.2.175.

Maguire, G. (2010). Wicked. Życie i czasy Złej Czarownicy z Zachodu (M. Wyrwas-Wiśniewska, tłum.). Kraków: Initium. (wyd. oryg. 1995).

Mochocka, A. (2017). Two perspectives on the performative social body: Teenage make-up routines in Fanfik and the Jeżycjada cycle. Miscellanea Posttotalitariana Wratislaviensia, 2, 87-115.

Nadolna-Tłuczykont, M. (2017). Tabu w literaturze dla młodego czytelnika. W: K. Tałuć (red.), Literatura dla dzieci i młodzieży. Tom 5 (s. 79-95). Katowice: Wydawnictwo UŚ.

Nowak, S. (2014). Homofobia. W: M. Rudaś-Grodzka, K. Nadana-Sokołowska, A. Mrozik, K. Szczuka, K. Czeczot, B. Smoleń, ... A. Wróbel (red.), Encyklopedia gender. Płeć w kulturze (s. 198-200). Warszawa: Czarna Owca.

Onichimowska, A. (2012). Koniec gry. Łódź: Literatura.

Osińska, N. (2016). Fanfik. Warszawa: Wydawnictwo Krytyki Politycznej.

Osińska, N. (2017). Slash. Warszawa: Agora. 
Osińska, N. (2019). Fluff. Warszawa: Agora.

Schwartz, S. (muzyka i słowa), Holzman, W. (scen.). (2003, 30 października). Wicked. Przedstawienie na żywo w Gershwin Theatre, New York, NY.

Skowera, M. (2016). Oz - kraina dzieciństwa czy imperium dorosłych? Dokąd prowadzi droga z żółtej kostki w utworach L. Franka Bauma i Gregory’ego Maguire’a. W: W. Kostecka, M. Skowera (red.), Geografia krain zmyślonych. Wokół kategorii miejsca i przestrzeni w literaturze dziecięcej, młodzieżowej i fantastycznej (s. 287-307). Warszawa: Wydawnictwo SBP.

Sobolczyk, P. (2014). Przekroczyć społeczną barierę „deprawacji nieletniego”. Bohater homoseksualny w literaturze dla dzieci i młodzieży. W: B. Niesporek-Szamburska, M. Wójcik-Dudek (red.), Wyczytać świat - międzykulturowość w literaturze dla dzieci i młodzieży (s. 105-122). Katowice: Wydawnictwo UŚ.

Strzelec, A. (1992). Byłam mężczyzną. Warszawa: Dom Wydawniczy Szczepan Szymański.

Strzelecka, A. (2004). Rola zjawiska transseksualizmu w procesie przekraczania barier płci. W: A. Kuczyńska, E. Dzikowska (red.), Zrozumieć płeć. Studia interdyscyplinarne II (s. 479-485). Wrocław: Wydawnictwo UWr.

Szybowicz, E. (2017). Tęcza nad Areną. Wyborcza.pl - Magazyn Poznański. Pobrane z: http://poznan.wyborcza.pl/poznan/7,105531,21966119,eliza-szybowicz-o-ksiazce-fanfik-natalii-osinskiej-tecza.html.

Śmieja, W. (2010). Literatura, której nie ma. Szkice o polskiej „literaturze homoseksualnej". Kraków: TAiWPN Universitas.

Werra, M. (2016). Fanfik miłosny, erotyczny czy ze slashem? Oblicza miłości w utworach internetowych fanów. Ogrody Nauk i Sztuk, 6(6), 479-484. https://doi. org/10.15503.onis2016.479.484/.

Wróblewski, M. (2018). Zmącone nadzieje, czyli literatura „czwarta” na najwyższym biegu. Polonistyka. Innowacje, 7, 29-39. https://doi.org/10.14746/pi.2018.7.3.

Zamojski, D. (2005). Aleksandra Zamojska jest mężczyzną. Warszawa: Lambda.

Zwolińska, B. (2003). Poganka Narcyzy Żmichowskiej jako romantyczna powieść inicjacyjna. W: W. Gutowski, E. Owczarz (red.), Z problemów prozy. Powieść inicjacyjna (s. 119-125). Toruń: Dom Wydawniczy Duet. 